\title{
Caffeine Modulates TNF- $\alpha$ Production by Cord Blood Monocytes: The Role of Adenosine Receptors
}

\author{
RAUL CHAVEZ-VALDEZ, MARSHA WILLS-KARP, RAJNI AHLAWAT, ELIZABETH A. CRISTOFALO, AMY NATHAN, \\ AND ESTELLE B. GAUDA
}

\begin{abstract}
Department of Pediatrics [R.C.-V., R.A., E.A.C., E.B.G.], Johns Hopkins University School of Medicine, Baltimore, Maryland 21287; Division of Immunology [M.W.-K., A.N.], University of Cincinnati College of Medicine, Cincinnati, Ohio 45229
\end{abstract}

\begin{abstract}
Caffeine, a nonspecific adenosine receptor (AR) antagonist is widely used to treat apnea of prematurity. Because adenosine modulates multiple biologic processes including inflammation, we hypothesized that AR blockade by caffeine would increase cytokine release from neonatal monocytes. Using cord blood monocytes (CBM), we investigated 1) the changes in AR mRNA profile by real time quantitative reverse-transcription polymerase-chain-reaction (qRT-PCR) and protein expression (western blot) after in vitro culture, caffeine or lipopolysaccharide (LPS) exposure, and 2) the modulation of cytokine release and cyclic adenosine monophosphate (cAMP) production by enzyme-linked immunosorbent assay (ELISA) induced by caffeine and specific $A R$ antagonists: $\operatorname{DPCPX}\left(\mathrm{A}_{1} \mathrm{R}\right)$, ZM241385( $\left.A_{2 a} R\right), \operatorname{MRS} 1754\left(A_{2 b} R\right)$, and MRS1220(A $\left.A_{3} R\right)$. After $48 \mathrm{~h}$ in culture, $\mathrm{A}_{2 \mathrm{a}} \mathrm{R}$ and $\mathrm{A}_{2 \mathrm{~b}} \mathrm{R}$ gene expression increased $1.9(p=0.04)$ and 2.5-fold ( $p=0.003$ ), respectively. $\mathrm{A}_{1} \mathrm{R}$ protein expression directly correlated with increasing LPS concentrations $(p=0.01)$, with minimal expression preexposure. Only caffeine $(50 \mu \mathrm{M})$ and DPCPX (10 nM) decreased tumor necrosis factor-alpha (TNF- $\alpha$ ) release from LPS activated-CBM by 20 and $25 \%(p=0.01)$ and TNF- $\alpha$ gene expression by 30 and $50 \%$, respectively, in conjunction with a $\geq 2$-fold increase in cAMP $(p<0.05)$. AR blockade did not modulate other measured cytokines. The induction of $A_{1} R$ after LPS exposure suggests an important role of this receptor in the control of inflammation in neonates. Our findings also suggest that caffeine, via $\mathrm{A}_{1} \mathrm{R}$ blockade, increases cAMP production and inhibits pretranscriptional TNF- $\alpha$ production by CBM. (Pediatr Res 65: 203-208, 2009)
\end{abstract}

$\mathrm{C}$ affeine $(1,3,11$ trimethylxantine) is a stimulant widely used in neonatology to treat apnea of prematurity (1). At therapeutic range ( 5 to $15 \mu \mathrm{g} / \mathrm{mL}$ ), caffeine blocks $A_{1}$ and $A_{2 a}$ adenosine receptors (ARs) stimulating ventilation (2-4). Recently, caffeine has also been linked to a decrease in the incidence of bronchopulmonary dysplasia and cerebral palsy in extremely premature infants $(5,6)$, although the mechanisms explaining these findings have not been elucidated.

Received June 12, 2008; accepted August 26, 2008.

Correspondence: Raul Chavez-Valdez, M.D., Department of Pediatrics, Division of Neonatology, Johns Hopkins Medical Institutions, Johns Hopkins Hospital, $600 \mathrm{~N}$. Wolfe Street, CMSC 6-104, Baltimore, MD 21287; e-mail: rchavez2@jhmi.edu

Supported by The Johns Hopkins University School of Medicine General Clinical Research Center grant M01-RR00052; The National Center for Research Resources/ NIH; The National Institutes of Health grant HL-072748 (E.B.G); The Johns Hopkins University Institutional Research Grant; and The Thomas Wilson Sanitarium for Children of Baltimore City.

This article contains supplemental material, which is available online at www. pedresearch.org.
The natural ligand for ARs, adenosine, has a crucial role in multiple biologic processes including inflammation $(7,8)$. The increase in tumor necrosis factor-alpha (TNF- $\alpha$ ) release by adult peripheral blood monocytes (PBM) in response to lipopolysaccharide (LPS) exposure can be abolished by pretreatment with $\mathrm{A}_{2 \mathrm{a}} \mathrm{R}$ agonists $(9,10)$. Adenosine binding to $A_{1} R(11,12)$ and $A_{3} R(13,14)$ also modulates TNF- $\alpha$ release from adult monocytes, whereas $A_{2 b} R$ appears to have little effect (10).

Little is known about AR expression on neonatal monocytes and the role of caffeine in modulating cytokine release. We hypothesized that caffeine blockade of ARs on neonatal monocytes would increase the release of cytokines in response to LPS. To test this hypothesis, we used cord blood monocytes (CBM) from full-term infants to 1) characterize the changes in AR mRNA profile and protein expression after $48 \mathrm{~h}$ in culture, exposure to caffeine and activation with LPS; and 2) determine the effect of AR blockade by caffeine on the release of pro- and antiinflammatory cytokines with indirect confirmation of AR function via determination of changes in intracellular cyclic adenosine monophosphate (cAMP) levels and cytokine gene expression.

\section{METHODS}

Subjects. This study complied with the Guidelines for Human Experimentation from the United States Department of Health and Human Services and received approval of The Johns Hopkins Medicine Institutional Review Board (NA_00002034). Informed consent was obtained from parents before inclusion in this study.

CBM from full-term infants ( $\geq 37$ wk gestation at birth) and PBM from adult volunteers were used for experiments. Cord blood was collected after repeat cesarean section without labor or vaginal delivery without evidence of chorioamnionitis. We excluded births with known genetic disorder, intrauterine growth restriction or small for gestational age (birth weight $\leq 10$ th percentile for gestational age), and suspected viral infection (based on maternal serological or clinical findings). Infants who subsequently received antibiotics or had illness sufficient to be admitted to the neonatal intensive care unit (NICU) were removed from analysis. Healthy adult volunteers, who were not using theophylline, were included in the study. Caffeine levels were obtained on all blood samples.

Isolation of cord blood monocytes. Full-term cord blood and adult peripheral blood were collected in EDTA for monocyte isolation and in no-additive tubes for caffeine level determination (BD Biosciences, Franklin Lakes, NJ). All blood samples were centrifuged at $2400 \times \mathrm{g}$ for $10 \mathrm{~min}$ at $25^{\circ} \mathrm{C}$, cellular portion was reconstituted in DPBS ( $\mathrm{pH} 7.4$; Mediatech,

\footnotetext{
Abbreviations: AR, adenosine receptor; CBM, cord blood monocytes; IQR, interquartile range; LPS, lipopolysaccharide; PBM, peripheral blood monocytes
} 
Inc., Herndon, VA) and monocytes were isolated using Ficoll-Hypaque gradient (GE Healthcare Biosciences AB, Uppsala, Sweden). Monocytes were then washed and reconstituted in $4 \times$ RPMI 1640 media containing $8 \%$ (vol/vol) [Delta]H human $\mathrm{AB}$ serum, penicillin/streptomycin (400 $\mathrm{IU} / \mathrm{mL} / 400 \mu \mathrm{g} / \mathrm{mL}$ ), and $8 \mathrm{mM}$ L-glutamine (Sigma Chemical,Aldrich, St. Louis, MO). Viable monocytes were used in experiments as outlined below.

Real time quantitative reverse-transcription polymerase-chain reaction. Total RNA was extracted from monocytes to determine changes in 1) $A_{1} R$, $A_{2 a} R, A_{2 b} R$, and $A_{3} R$ gene expression after $48 \mathrm{~h}$ in culture $\left(37^{\circ} \mathrm{C} / 5 \% \mathrm{CO}_{2}\right)$, caffeine exposure $(50 \mu \mathrm{M})$ and LPS activation $(0,100$, and $200 \mathrm{ng} / \mathrm{mL})$, and 2) TNF- $\alpha$ gene expression after caffeine and DPCPX (10 nM) treatments alone and combined. PureLink Micro-to-midi total RNA purification system (Invitrogen, Carlsbad, CA) was used according to specifications. Approximately $1 \mu \mathrm{g}$ of total RNA was used for generation of complementary DNA (cDNA) using iScript cDNA synthesis kit (BioRad, Hercules, CA). Reverse transcription protocol included $5 \mathrm{~min}$ at $25^{\circ} \mathrm{C} ; 30 \mathrm{~min}$ at $42^{\circ} \mathrm{C}$; and $5 \mathrm{~min}$ at $85^{\circ} \mathrm{C}$. cDNA was then used to amplify target genes by real time quantitative reverse-transcription polymerase-chain-reaction (qRT-PCR) using $300 \mathrm{nM}$ concentration of primers [Table 1; (15-19)]. SYBR Green Supermix (BioRad) was used for signal detection by MyIQ PCR Thermocycler (BioRad). Two different amplification protocols were used 1) for ARs: 40 cycles of $15 \mathrm{~s}$ at $95.0^{\circ} \mathrm{C}, 1 \mathrm{~min}$ at $60.0^{\circ} \mathrm{C}$, and $30 \mathrm{~s}$ at $72.0^{\circ} \mathrm{C}$; and 2) for TNF- $\alpha$ : 40 cycles of $1 \mathrm{~min}$ at $94.0^{\circ} \mathrm{C}, 1 \mathrm{~min}$ at $60.0^{\circ} \mathrm{C}$, and $2 \mathrm{~min}$ at $72.0^{\circ} \mathrm{C}$. The fold difference in gene expression was corrected to GAPDH (human glyceraldehyde phosphate dehydrogenase; reference gene) using the Pfaffl method (20). Melting curves were used to ascertain purity of PCR products, which were also visualized by $1.3 \%$ gel electrophoresis.

Western blot analysis. Changes in $\mathrm{A}_{1} \mathrm{R}$ and $\mathrm{A}_{2 \mathrm{a}} \mathrm{R}$ protein expression on CBM after $24 \mathrm{~h}$ LPS exposure $(0,100$, and $200 \mathrm{ng} / \mathrm{mL})$ were determined using western blot. Protein was extracted by manually homogenizing monocytes followed by ice-cold ethanol precipitation. Protein pellet was reconstituted in 0.01 M PBS (pH 7.4; Quality Biologic, Gaithersburg, MD) and concentration was determined using the Bradford method. Twenty five microgram of protein were diluted in loading buffer containing $20 \%$ (wt/vol) glycerol and loaded on to $12 \%$ SDS-PAGE. Proteins were transferred to nitrocellulose membrane, stained with Ponceau S, blocked with $2.5 \%$ nonfat dry milk with $0.1 \%$ Tween 20 in $50 \mathrm{mM}$ Tris buffered saline ( $\mathrm{pH} 7.4)$, and consecutively incubated overnight at $4{ }^{\circ} \mathrm{C}$ with polyclonal rabbit anti- $\mathrm{A}_{1} \mathrm{R}$ (Sigma Chemical, Aldrich), or monoclonal mouse anti- $\mathrm{A}_{2 \mathrm{a}} \mathrm{R}$ antibodies (Upstate, Lake placid, NY) both at $1: 1000$, or mouse anti- $\beta$-actin MAb (Sigma Chemical, Aldrich) at 1:20,000. The membrane was then washed with milk, exposed to goat anti-rabbit or anti-mouse antibodies (Bio-Rad) at 1:10,000 for $1 \mathrm{~h}$ and then developed with enhanced chemiluminescence using SuperSignal kit (Thermo Scientific,
Rockford, IL). To quantify protein immunoreactivity, films were scanned using Adobe Photoshop, and optical density (OD) was determined with IP Lab Gel $\mathrm{H}$ software adjusting for background $(\Delta \mathrm{OD}) . \beta$-actin was used for protein loading correction. Protein levels are expressed as relative OD measurements (arbitrary density units; ADU).

Enzyme-linked immunosorbent assay. Caffeine and specific AR antagonists [Table 2; (4,21-24)] were used to investigate the role of ARs in modulating cytokine release. Concentrations were based on $\mathrm{IC}_{50}$ and $\mathrm{K}_{\mathrm{i}}$ to maximize specificity to each AR. A total of $50 \mu \mathrm{M}$ of caffeine was within therapeutic range for neonates treated for apnea of prematurity $(5-15 \mu \mathrm{g} / \mathrm{mL})$. Caffeine was prepared in acidic water (citric acid based, $\mathrm{pH} 4.7$ ) and titrated to $\mathrm{pH} 7.3$ before use. All other antagonists were reconstituted in DMSO (DMSO, cell-culture-concentration: $2.7 \times 10^{-6} \mathrm{~g} / \mathrm{mL}$ ). ZM241385 was purchased from Tocris Bioscience (Ellisville, MO), and all other drugs were purchased from Sigma Chemical. Monocytes were exposed to caffeine, ZM241385, MRS1754, or MRS1220 in initial experiments and to caffeine and DPCPX alone and combined in additional experiments. After exposure to these conditions for $75 \min \left(37^{\circ} \mathrm{C} / 5 \% \mathrm{CO}_{2}\right)$, monocytes were activated using Escherichia coli K235 LPS (100 ng/mL; Sigma Chemical, Aldrich). After $24 \mathrm{~h}$, supernatants were recovered for subsequent determination of cytokine (TNF- $\alpha$, IL-1 $\beta$, IL-6, and IL-10) concentrations by enzyme-linked immunosorbent assay (ELISA) using LINCOplex Multiplex kits (Millipore, Billerica, MA) according to manufacturer's protocol and concentrations were calculated using the Luminex detection system (Millipore).

Intracellular cAMP levels were measured to confirm functionality of ARs during exposure to caffeine and/or DPCPX. After exposure, monocytes were lysed using $2.5 \%$ dodecyltrimethylammonium bromide in assay buffer $(\mathrm{pH}$ 5.8; 0.05 M sodium acetate buffer and 0.02\% BSA). Intracellular cAMP levels were measured using the Amersham cAMP EIA System (GE Healthcare, Little Chalfont, Buckinghamshire, UK) and results were reported as percentage change from baseline (no-treatment) corrected for $2 \times(10)^{5}$ viable monocytes.

Statistical analysis. Because of the non-normal distribution of the data, nonparametric statistics, including Wilcoxon signed rank test, Mann-Whitney test, Friedman analysis of variance (ANOVA), and Spearman Rank correlation were used. Results are reported as median with interquartile range (IQR, 25 to 75th percentile) and, in most cases, represented as box-and-whisker plots with outliers (boxes symbolize IQR). Additional analysis of the data, including correlations and multilevel analysis were performed to investigate the persistency of the effect attributed to caffeine on TNF- $\alpha$ release after correcting for the influence of other measured cytokines (supplemental material online, www.pedresearch.org). Significance was assigned by $p<0.05$. SPSS 14.0 software was used.

Table 1. Primers for real time $q R T-P C R(15-19)$

\begin{tabular}{|c|c|c|c|}
\hline Gene & Direction & Sequence & PCR-product \\
\hline \multirow[t]{2}{*}{$\mathrm{A}_{1} \mathrm{R}$} & S & 5'-CACCTTCTGCTTCATCGTGTC-3' & 308-bp \\
\hline & AS & 5'-AGCCAAACATAGGGGTCAGTC-3' & \\
\hline \multirow[t]{2}{*}{$\mathrm{A}_{2 \mathrm{a}} \mathrm{R}$} & S & 5'-AACCTGCAGAACGTCACCAA-3' & 245-bp \\
\hline & AS & 5'-GTCACCAAGCCATTGTACCG-3' & \\
\hline \multirow[t]{2}{*}{$\mathrm{A}_{2 \mathrm{~b}} \mathrm{R}$} & $\mathrm{S}$ & 5'-GTCATTGCTGTCCTCTGG-3' & 298-bp \\
\hline & AS & 5'-TCCTCGAGTGGTCCATCAG-3' & \\
\hline \multirow[t]{2}{*}{$\mathrm{A}_{3} \mathrm{R}$} & S & 5'-ACCAGCTCATTGTCACTATG-3' & 311-bp \\
\hline & AS & 5'-ACTTCTCCTCCTTTTGGTCA-3' & \\
\hline \multirow[t]{2}{*}{ TNF- $\alpha$} & S & 5'-GAGTGACAAGCCTGTAGCCCATGTTGTAGCA-3' & 444-bp \\
\hline & AS & 5'-GCAATGATCCCAAAGTAGACCTGCCCAGACT-3' & \\
\hline \multirow{2}{*}{ GAPDH } & $\mathrm{S}$ & 5'-AACAGCGACACCCACTCCTC-3' & 258-bp \\
\hline & AS & 5'-GGAGGGGAGATTCAGTGTGGT-3' & \\
\hline
\end{tabular}

bp, base pair; GADPH, glyceraldehyde phosphate dehydrogenase; qRT-PCR, quantitative reverse transcription-polymerase chain reaction; TNF- $\alpha$, tumor necrosis factor-alpha; S, sense; AS, antisense.

Table 2. Adenosine receptor antagonists (4,21-24)

\begin{tabular}{llcc}
\hline AR Antagonist & \multicolumn{1}{c}{ Synonym } & Concentration & Target receptor \\
\hline Caffeine & 1,3,7-Trimethylxanthine & $50 \mu \mathrm{M}$ & $\mathrm{A}_{1}, \mathrm{~A}_{2 \mathrm{a}}, \mathrm{A}_{2 \mathrm{~b}}$ \\
DPCPX & 1,3-Dipropyl-8cyclopentylxanthine & $10 \mu \mathrm{M}$ & $\mathrm{A}_{1}$ \\
ZM241385 & 4-(2-[7-Amino-2-[2-furyl][1,2,4]triazolo[2,3-a][1,3,5]triazin-5-yl-amino]ethyl) phenol & $10 \mu \mathrm{M}$ & $\mathrm{A}_{2 \mathrm{a}}$ \\
MRS1754 & 8-[4-[(4 Cyanophenyl)carbamoylmethyl)oxy]phenyl]- 1,3-di(n-propyl)xanthine & $10 \mu \mathrm{M}$ & $\mathrm{A}_{2 \mathrm{~b}}$ \\
MRS1220 & 9-Chloro-2-(2-furanyl)-5-((phenylacetyl)amino)-[1,2,4]triazolo[1,5-c] quinazoline & $1 \mu \mathrm{M}$ & $\mathrm{A}_{3}$ \\
\hline
\end{tabular}




\section{RESULTS}

Cord blood from 28 neonates (mean gestational age \pm $\mathrm{SD}=392 / 7 \pm 1.3 \mathrm{wk}$; birth weight $=3312 \pm 513 \mathrm{~g}$; Table 3) and peripheral blood from eight adult volunteers (age $=$ $40.9 \pm 9.9$ y) were used for in vitro experiments. Serum caffeine concentrations were below the therapeutic range (mean $\pm \mathrm{SD}=1.2 \pm 1.4 \mu \mathrm{g} / \mathrm{mL}$ for neonates and $2.4 \pm 2$ $\mu \mathrm{g} / \mathrm{mL}$ for adults) and were not statistically different between age groups.

Effect of culture and caffeine on AR gene expression in CBM. $\mathrm{A}_{1} \mathrm{R}$ gene expression was undetected in full-term CBM whereas PCR products of alternative splicing variants expressed at baseline, and after $48 \mathrm{~h}$ in culture in adult PBM, showing alternative splicing products. In CBM, after $48 \mathrm{~h}$ in culture, $\mathrm{A}_{2 \mathrm{a}} \mathrm{R}$ mRNA expression increased 1.9-fold (IQR 0.5$11.8 ; p=0.04$ ) and $\mathrm{A}_{2 \mathrm{~b}} \mathrm{R}$ mRNA increased 2.5-fold (IQR $1.6-3.5, p=0.003)$. As a comparison, culture conditions did not change $A_{2 a} R$ mRNA expression but did increase $A_{2 b} R$ mRNA expression by 2.3-fold (IQR 1.3-7.2, $p=0.03$ ) in adult PBM (Fig. 1). In vitro exposure to caffeine did not further modify the gene expression of any AR subtype.

Effect of LPS exposure on AR expression in CBM. Although $\mathrm{A}_{1} \mathrm{R}$ mRNA was not detected in CBM at baseline by real time qRT-PCR (Fig. 1A), $24 \mathrm{~h}$ exposure to LPS (100

Table 3. Demographics and serum caffeine in neonates

\begin{tabular}{lc}
\hline \multicolumn{1}{c}{ Full-term infants $(n=28)$} & \\
\hline Gestational age (mean $\pm \mathrm{SD})$ & $392 / 7 \pm 1.3 \mathrm{wk}$ \\
Birth weight (mean $\pm \mathrm{SD})$ & $3312 \pm 513 \mathrm{~g}$ \\
Gender & $68 \% \mathrm{male}$ \\
Race & $64 \% \mathrm{AA} ; 12 \% \mathrm{C}$ \\
APGARS 1 min (median, range) & $8(7-9)$ \\
APGARS 5 min (median, range) & $9(8-9)$ \\
Delivery mode & $60 \% \mathrm{SVD} ; 40 \% \mathrm{C} / \mathrm{s}$ \\
Caffeine level (mean $\pm \mathrm{SD})$ & $1.2 \pm 1.4 \mu \mathrm{g} / \mathrm{mL}$ \\
\hline
\end{tabular}

AA, African American; APGARS, apgar score; C, Caucasian; C/s, cesarean section delivery; SD, standard deviation; SVD, spontaneous vaginal delivery.

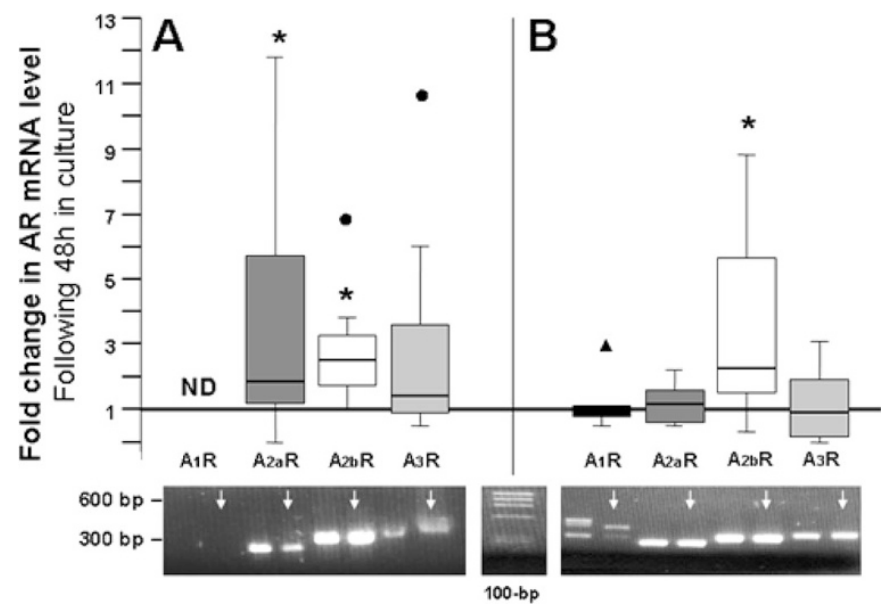

Figure 1. Fold change in AR mRNA levels after $48 \mathrm{~h}$ in-culture. (A) Neonates $(n=12)$ and $(B)$ Adults $(n=8)$. Solid line inside boxes represents median. $\bullet$, Extremes; $\bullet$, outliers. $* p<0.05$ (Wilcoxon signed rank test) versus reference line (at 1 , no change). ND, nondetected. Electrophoresis shows RT-PCR products before and after culture, arrows identify products after culture. $\mathrm{ng} / \mathrm{mL})$ induced the expression of this gene in $67 \%(n=8 / 12)$ of the subjects with no further induction at higher LPS concentration (200 ng/mL). Electrophoresis (Fig. 2A) showed $\mathrm{A}_{1} \mathrm{R}$ PCR products at $308-\mathrm{bp}$, which corresponds to the two recognized transcript variants (NM_000674.2 and NM_001048230.1; NCBI database). Nontranslated products of alternative splicing are shown at 455-bp (Alternative Splicing and Transcript Diversity Database; www.ebi.ac.uk/astd). LPS exposure also increased $\mathrm{A}_{2 \mathrm{a}} \mathrm{R}$ mRNA expression by 4.2-fold (IQR 3.6-12.2; $p=0.02$; Fig. 2B).

Western blot analysis showed that $A_{1} R$ and $A_{2 a} R$ protein expression directly correlated with LPS concentrations to which CBM were exposed ( $r=0.64, p=0.01$ and $r=0.71$, $p=0.001$, respectively). LPS at 100 and $200 \mathrm{ng} / \mathrm{mL}$, increased $\mathrm{A}_{1} \mathrm{R}$ protein by $35 \%$ (IQR 18 to $360 \% ; p=0.03$ ) and $100 \%$ (IQR 41 to $785 \% ; p=0.03$ ), respectively $(p=0.002$, Friedman ANOVA; Fig. $2 C$ and $D$ ) and increased $\mathrm{A}_{2 \mathrm{a}} \mathrm{R}$ protein by $174 \%$ (IQR 16 to $455 \% ; p=0.02$ ) and $230 \%$ (IQR 36 to $621 \% ; p=0.02$ ), respectively, versus no LPS exposure ( $p=0.006$, Friedman ANOVA).

Effect of AR antagonists on cytokine release from LPSactivated monocytes. Exposure to LPS significantly increased the release of all measured cytokines (TNF- $\alpha$, IL- $1 \beta$, IL-6, and IL-10) from CBM and adult PBM compared with control conditions $(p<0.05)$. In response to LPS, cytokine release did not differ between neonates and adults, except for the antiinflammatory cytokine, IL-10, which showed 80\% (IQR 69 to $96 \%, p=0.04$ ) less release from CBM compared with adults PBM (Fig. 3). Mode of delivery did not influence baseline cytokine levels or response to antagonists.

In LPS-activated CBM, caffeine (a nonspecific AR antagonist) down-regulated TNF- $\alpha$ release by $20 \%$ from baseline (IQR -40 to $-9 \%, p=0.015$ ) whereas $\mathrm{A}_{2 \mathrm{a}} \mathrm{R}, \mathrm{A}_{2 \mathrm{~b}} \mathrm{R}$, and $\mathrm{A}_{3} \mathrm{R}$ specific antagonists did not produce an effect. In experiments using adult PBM, there was a trend toward an increase in TNF- $\alpha$ release from baseline after exposure to all AR antagonists with MRS1220 ( $\mathrm{A}_{3} \mathrm{R}$ antagonist) reaching significance $(p=0.03)$. The differences in TNF- $\alpha$ release between CBM and adult PBM after caffeine and ZM241385 reached significance $(p=0.02$ and 0.03 for each treatment, respectively; Fig. 4A). Caffeine and specific antagonists did not affect IL-1 $\beta$, IL-6, and IL-10 release from monocytes in either age group (data not shown). Because the observed decrease in TNF- $\alpha$ release by CBM following caffeine exposure (Fig. 4A) can result from 1) the blockade of ARs and/or 2) the interaction with other cytokines, we determined the influence of these two factors using a multilevel model. Correcting for interactions with other cytokines, the model supported our initial findings associating caffeine with down-regulation of TNF- $\alpha$ release $(-56 \%, \beta=-303 \pm 66 \mathrm{pg} / \mathrm{mL} ; p=0.01)$. The mechanism behind this effect was explored in the next series of experiments.

Role of $A_{1} R$ in the decrease of TNF- $\alpha$ release from CBM. Because specific $A_{2 a} R, A_{2 b} R$, and $A_{3} R$ antagonists did not affect the release of TNF- $\alpha$ and LPS exposure induced $A_{1} R$ gene and protein expression, we hypothesized that $A_{1} R$ was involved in the reduction of TNF- $\alpha$ secretion after caffeine exposure. DPCPX, a specific $\mathrm{A}_{1} \mathrm{R}$ antagonist $(10 \mathrm{nM})$, down- 
A

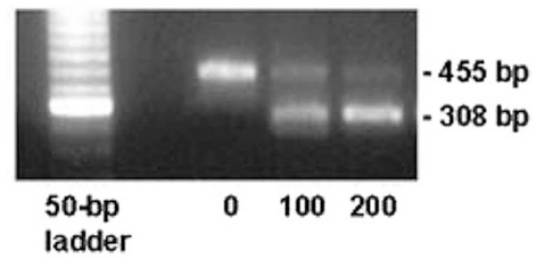

B
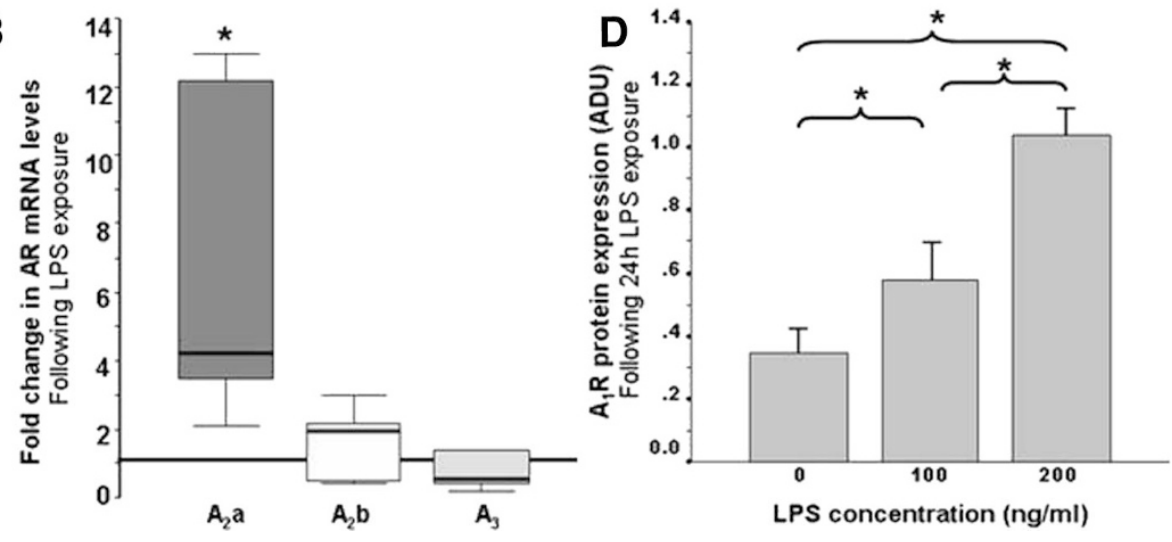

Figure 2. Effect of LPS exposure on AR gene and protein expression. (A) RT-PCR products for $A_{1} R$ from CBM after LPS exposure $(0,100$, and $200 \mathrm{ng} / \mathrm{mL}$ ). Transcript variants were amplified as 308-bp products (455-bp product is result of alternative splicing). (B) Fold change in AR mRNA on CBM after $24 \mathrm{~h}$ LPS exposure at $100 \mathrm{ng} / \mathrm{mL}(n=8)$. Solid line inside boxes represents median. $* p<0.05$ (Wilcoxon signed rank test) versus reference line (at 1 , no change). (C) Western blot showing $\mathrm{A}_{1} \mathrm{R}$ protein at $\sim 36 \mathrm{kD}$ band in $12 \%$ SDS-PAGE, and $(D) \mathrm{A}_{1} \mathrm{R}$ protein levels expressed as arbitrary density units (ADU) adjusted to $\beta$-actin. Data as mean \pm SEM (ADU) after exposure to LPS at 0,100 , and $200 \mathrm{ng} / \mathrm{mL}$ $(n=6) . * p<0.05$ (Wilcoxon signed rank test); overall $p=0.001$ (Friedman ANOVA).

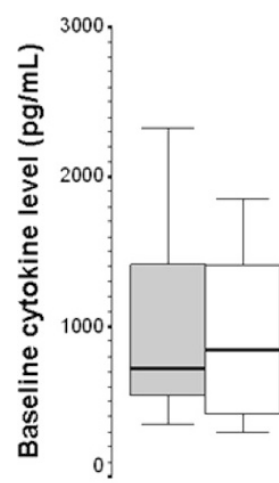

TNF-a

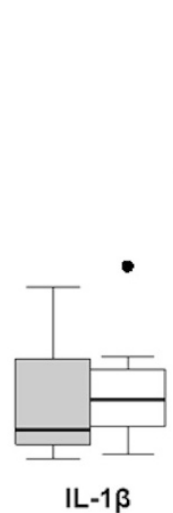

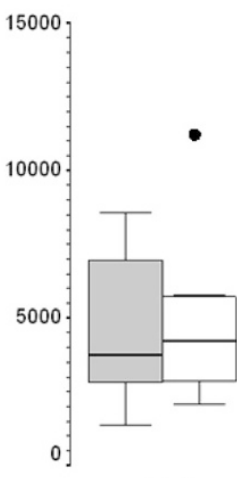

IL-6

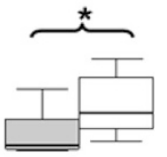

IL-10
Figure 3. Cytokines $(\mathrm{pg} / \mathrm{mL}$ ) released from neonatal (gray box) and adult (white boxes) monocytes after exposure to LPS (100 ng/mL). Solid line inside boxes represents median. $* p<0.05$ (Mann-Whitney test). $\bullet$, outliers $(n=12)$.

regulated TNF- $\alpha$ release by $25 \%$ from baseline (IQR -54 to $-8 \%, p=0.01)$ and the addition of caffeine to cells pretreated with DPCPX down-regulated TNF- $\alpha$ release by a total of $43 \%$ from baseline (IQR -70 to $-26 \%, p=0.01$ ). The additional decrease in TNF- $\alpha$ release produced by caffeine after pretreatment with DPCPX was significant ( $p=0.03$ versus DPCPX alone; $p=0.001$ by Friedman ANOVA; Fig. $4 B$ ).

In accordance with these findings outlined above, caffeine increased intracellular cAMP levels by 2.8-fold (IQR 2.3-3.8, $p=0.04$ ) and DPCPX by 2.1 -fold from baseline (IQR $1.6-$ $2.3, p=0.03)$. The addition of caffeine after pretreatment with DPCPX increased cAMP by 2-fold (IQR 1.7-2.2, $p=0.04$ ) from baseline, similar to DPCPX alone (Fig. 4C). Caffeine inhibited TNF- $\alpha$ gene expression by $30 \%$ (IQR -10 to $-40 \%, p=0.01$ ) whereas DPCPX inhibited the gene by $50 \%$ (IQR -40 to $-50 \%, p=0.04$; Fig. $4 D$ ).

\section{DISCUSSION}

In this study, we determined the change in AR expression in full-term CBM compared with that on adult PBM after in vitro culture and exposure to caffeine or LPS. We also determined the effect of caffeine on cytokine release from CBM and indirectly confirmed the AR function by measuring the changes in cAMP production and TNF- $\alpha$ gene expression. We demonstrated that in contrast to adult PBM, $\mathrm{A}_{1} \mathrm{R}$ gene and protein expression in CBM is minimal until exposure to LPS, which also up-regulates $A_{2 \mathrm{a}} R$. We showed that TNF- $\alpha$ release in response to LPS is similar in CBM and adult PBM, and exposure to caffeine or DPCPX $\left(\mathrm{A}_{1} \mathrm{R}\right.$ antagonist) downregulates TNF- $\alpha$ release only from CBM. In accordance with these findings, we found that intracellular cAMP concentration increases and TNF- $\alpha$ gene expression decreases as a result of caffeine or DPCPX exposure. These data suggest that the effect of caffeine on TNF- $\alpha$ release was in part mediated via $\mathrm{A}_{1} \mathrm{R}$ blockade.

AR gene expression in monocytes differs between neonates and adults. The dose-related induction of $A_{1} R$ protein expression in CBM after LPS exposure could explain the baseline $A_{1} R$ expression observed in adult PBM. This finding suggests that $A_{1} R$ induction occurs some time after birth following exposure to infections and also implies, similar to $\mathrm{A}_{2 \mathrm{a}} \mathrm{R}$, a role in the modulation of inflammation $(8,25)$.

Because of the nonspecific effect of caffeine on ARs, the identification of the particular AR subtype(s) involved in the modulation of TNF- $\alpha$ release is challenging. We used specific AR antagonists to evaluate the effects of endogenous adenosine. We believe that this approach is most applicable to studying the effects of caffeine, a nonspecific AR antagonist, compared with the use of agonists.

$\mathrm{A}_{1} \mathrm{R}$ dysregulation leads to a proinflammatory state (11) and because of the high affinity of $A_{1} R$ (coupled to $G_{i}$-protein) for adenosine, $\mathrm{A}_{1} \mathrm{R}$ blockade could potentially increase cAMP not only directly but also indirectly by displacing adenosine toward $A_{2 a} R$ (coupled to $G_{s}$-protein), which ultimately will down-regulate TNF- $\alpha$ release $(26,27) . A_{1} R$ is directly induced in response to infection and oxidative stress in multiple cells (28). Our experiments using DPCPX demonstrate that the 


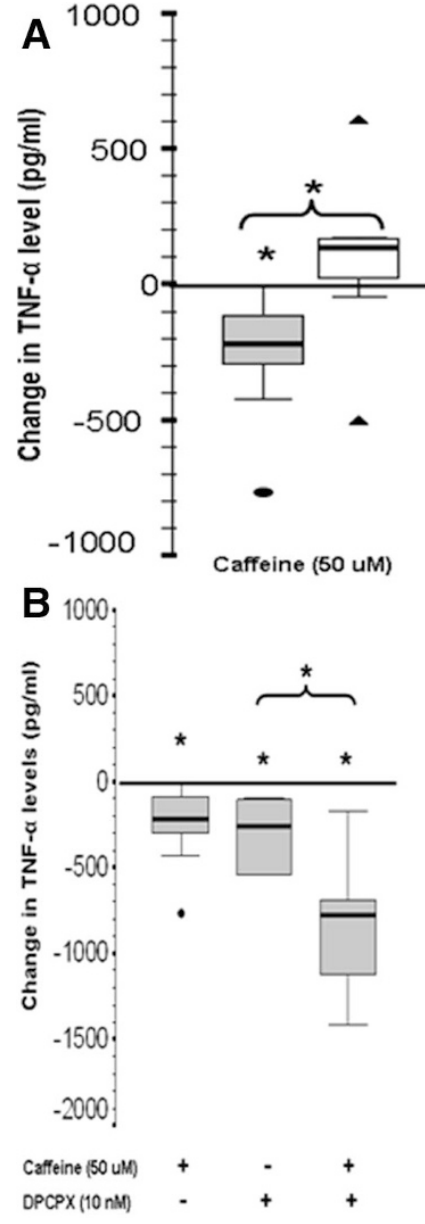

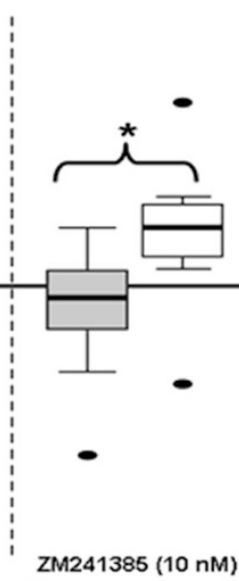

C

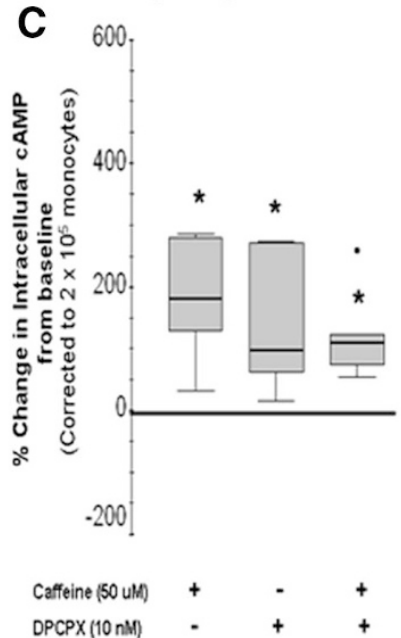

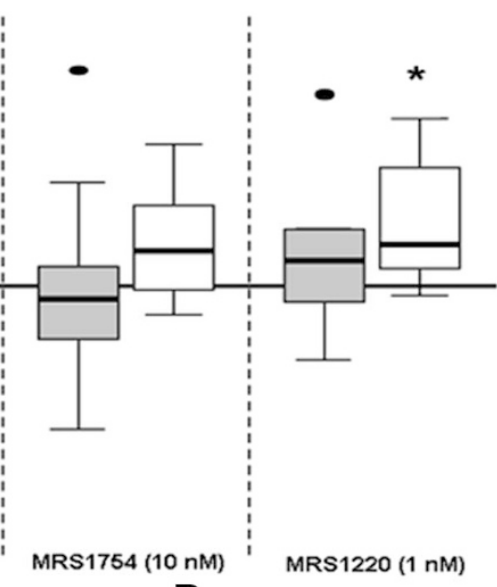

D

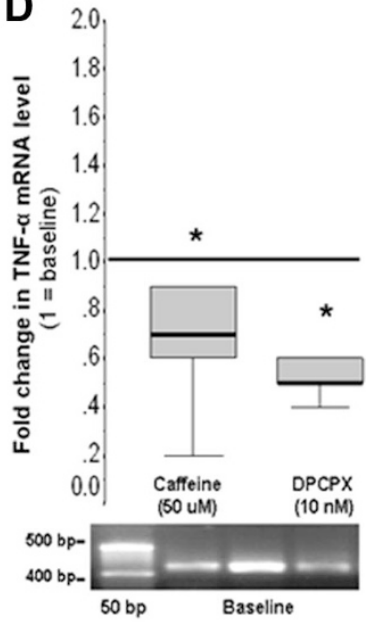

Figure 4. Effect of AR antagonists on TNF- $\alpha$ release. (A) Change from baseline in TNF- $\alpha$ $(\mathrm{pg} / \mathrm{mL})$ release from neonatal (gray boxes; $n=$ 12) and adult (white boxes; $n=8$ ) monocytes pretreated with caffeine and specific $\mathrm{A}_{2 \mathrm{a}} \mathrm{R}$, $\mathrm{A}_{2 \mathrm{~b}} \mathrm{R}$, and $\mathrm{A}_{3} \mathrm{R}$ antagonists. (B) Change in TNF- $\alpha(\mathrm{pg} / \mathrm{mL})$ release $(n=8) ;(C)$ Percentage change in intracellular cAMP concentrations $(n=6)$; and $(D)$ Fold change in TNF- $\alpha$ gene expression $(n=8)$ in LPS-activated CBM in response to caffeine and DPCPX alone and combined. Electrophoresis showed 444-bp RTPCR product for TNF- $\alpha$. Reference lines (baseline conditions), positioned at $0(A, B$, and $C)$ and $1(D)$, represent no change. Line inside boxes represents median. $* p<0.05$ (Wilcoxon signed rank test versus baseline and Mann-Whitney test, between age groups). $\mathbf{\wedge}$, extremes; $\bullet$, outliers.

blockade of $\mathrm{A}_{1} \mathrm{R}$ on LPS-activated CBM significantly downregulates TNF- $\alpha$ release, via a pretranscriptional mechanism, to levels similar to that after caffeine exposure. These findings strongly suggest that, at least in part, $\mathrm{A}_{1} \mathrm{R}$ blockade mediates the effect of caffeine on TNF- $\alpha$ release, which is also associated with concurrent changes in cAMP levels and TNF- $\alpha$ gene expression.

$\mathrm{A}_{2 \mathrm{a}} \mathrm{R}$ agonists down-regulate TNF- $\alpha$ release; $(10,29)$ however, specific $\mathrm{A}_{2 \mathrm{a}} \mathrm{R}$ antagonists (ZM 241385) failed to increase TNF- $\alpha$ release from adult PBM (30) or CBM (our data). This inconsistency may be related to the multiple AR subtypes differentially modulating cAMP production. As demonstrated by our data, LPS-activated CBM express the full spectrum of ARs identified to date, making possible that specific $A_{2 a} R$ blockade displaces adenosine to bind to other available receptors, including $\mathrm{A}_{2 \mathrm{~b}} \mathrm{R}$ and $\mathrm{A}_{3} \mathrm{R}$, which will increase cAMP production. Studies targeting the $\mathrm{A}_{2 \mathrm{~b}} \mathrm{R}$ are less abundant and conclusive and most show that in response to specific $A_{2 b} R$ agonists, TNF- $\alpha$ is up-regulated probably as a result of the concomitant IL-19 release (10,31). In our experiments, $\operatorname{MRS} 1754\left(\mathrm{~A}_{2 \mathrm{~b}} \mathrm{R}\right.$ antagonist) appears to have a role in downregulating TNF- $\alpha$ release (multilevel analysis, supplemental material online, www.pedresearch.org), however, its effect is abolished by the influence of other cytokines (Fig. 4A). Because caffeine simultaneously blocks $\mathrm{A}_{2 \mathrm{a}} \mathrm{R}$ and $\mathrm{A}_{2 \mathrm{~b}} \mathrm{R}$ and the blockade of the latter could potentially have an effect in the
TNF- $\alpha$ release, we cannot rule out that the mechanism of caffeine could also be directly or indirectly mediated by $A_{2 b} R$.

$\mathrm{A}_{3} \mathrm{R}$ activation has been linked to pro- and antiinflammatory effects, from pro- to antiinflammatory (14,26,32). Recently, $A_{3} R$ has been described as positively coupled to adenylyl cyclase, thereby increasing cAMP production upon activation $(33,34)$. Because caffeine, at $50 \mu \mathrm{M}$, blocks all ARs except for $\mathrm{A}_{3} \mathrm{R}$, we speculate that the downregulation of $\mathrm{TNF}-\alpha$ release associated with caffeine is also mediated by the indirect increase in $\mathrm{A}_{3} \mathrm{R}$ affinity for adenosine when the other ARs are blocked. This mechanism could explain our results showing an additional decrease in TNF- $\alpha$ release after caffeine is added to DPCPX pretreated CBM.

The synchronized increase of intracellular cAMP levels and decrease of TNF- $\alpha$ gene expression after caffeine exposure suggest that the decrease in TNF- $\alpha$ release is likely a pretranscriptional process. Several pathways related to accumulation of intracellular cAMP such as cAMP/protein kinase A (35) and modifications in $\mathrm{NF}-\kappa \mathrm{B}$ (36) are targets of our future experiments.

Although TNF- $\alpha$ release is modulated by caffeine via AR blockade, that is not the case for all cytokines. Multiple studies using adult PBM show that IL-1 $\beta$ (14,35), IL-6 (29), and IL-10 (35) release from these cells are not modulated by ARs. A recent study using neonatal monocytes reported similar finding related to IL-6 (32). We have extended this finding 
by also showing that IL-1 $\beta$ and IL-10 release are also independent of ARs in CBM.

In this article, we demonstrate the significant differences in AR mRNA profile between monocytes from neonates and adults, the induction of $A_{1} R$ gene and protein expression after LPS exposure and also the suppressive effect of caffeine on TNF- $\alpha$ release by LPS-activated CBM via mechanisms involving ARs. Our data suggest that $A_{1} R$ blockade is operative in mediating the effect of caffeine. Although the direct applicability of our findings to premature infants is still unclear, we believe that our results are clinically relevant to neonates exposed to caffeine either throughout gestation or postnatally. Whether the suppression of TNF- $\alpha$ release produced by caffeine has a beneficial effect by decreasing chronic inflammation or has a detrimental effect by increasing the risk for infection is unclear. Nevertheless, reduction in the incidence of chronic lung disease and periventricular leukomalacia in premature infants has been attributed to the use of caffeine citrate (5). Our data suggest a potential biologic mechanism to explain these clinical observations and add to the body of evidence characterizing the differences in inflammatory response between neonates and adults as it relates to ARs on monocytes.

Acknowledgments. The authors acknowledge Dr. Frances Northington and Dr. Lawrence Nogee for their support and helpful critiques; Mr. Reed Cooper for his initial assistance with RT-PCR; Mrs. Alyssa Sproles for her technical assistance with ELISA and monocyte isolation techniques; Mrs. Debra Flock, Ms. Ariel Mason, Mr. Wayne Hickok, and Mrs. Myra Black for their administrative assistance and the obstetric team at Johns Hopkins Hospital for their kind support with patient enrollment. They are also indebted with our patients and their families for their willingness to participate in this study.

\section{REFERENCES}

1. Herlenius E, Lagercrantz H, Yamamoto Y 1997 Adenosine modulates inspiratory neurons and the respiratory pattern in the brainstem of neonatal rats. Pediatr Res 42:46-53

2. Bona E, Aden U, Fredholm BB, Hagberg H 1995 The effect of long term caffeine treatment on hypoxic-ischemic brain damage in the neonate. Pediatr Res 38:312-318

3. Ferre S, Ciruela F, Borycz J, Solinas M, Quarta D, Antoniou K, Quiroz C, Justinova Z, Lluis C, Franco R, Goldberg SR 2008 Adenosine A1-A2A receptor heteromers: new targets for caffeine in the brain. Front Biosci 13:2391-2399

4. Fredholm BB, Irenius E, Kull B, Schulte G 2001 Comparison of the potency of adenosine as an agonist at human adenosine receptors expressed in Chinese hamster ovary cells. Biochem Pharmacol 61:443-448

5. Schmidt B, Roberts RS, Davis P, Doyle LW, Barrington KJ, Ohlsson A, Solimano A, Tin W 2006 Caffeine therapy for apnea of prematurity. N Engl J Med 354:21122121

6. Schmidt B, Roberts RS, Davis P, Doyle LW, Barrington KJ, Ohlsson A, Solimano A, Tin W 2007 Long-term effects of caffeine therapy for apnea of prematurity. N Engl J Med 357:1893-1902

7. Krump E, Lemay G, Borgeat $P 1996$ Adenosine A2 receptor-induced inhibition of leukotriene B4 synthesis in whole blood ex vivo. Br J Pharmacol 117:1639-1644

8. Hasko G, Pacher P, Deitch EA, Vizi ES 2007 Shaping of monocyte and macrophage function by adenosine receptors. Pharmacol Ther 113:264-275

9. Bshesh K, Zhao B, Spight D, Biaggioni I, Feokistov I, Denenberg A, Wong HR, Shanley TP 2002 The A2A receptor mediates an endogenous regulatory pathway of cytokine expression in THP-1 cells. J Leukoc Biol 72:1027-1036

10. Zhang JG, Hepburn L, Cruz G, Borman RA, Clark KL 2005 The role of adenosine $\mathrm{A} 2 \mathrm{~A}$ and $\mathrm{A} 2 \mathrm{~B}$ receptors in the regulation of TNF-alpha production by human monocytes. Biochem Pharmacol 69:883-889
11. Mayne M, Shepel PN, Jiang Y, Geiger JD, Power C 1999 Dysregulation of adenosine A1 receptor-mediated cytokine expression in peripheral blood mononuclear cells from multiple sclerosis patients. Ann Neurol 45:633-639

12. Sipka S, Kovacs I, Szanto S, Szegedi G, Brugos L, Bruckner G, Jozsef Szentmiklosi A 2005 Adenosine inhibits the release of interleukin-1beta in activated human peripheral mononuclear cells. Cytokine 31:258-263

13. Martin L, Pingle SC, Hallam DM, Rybak LP, Ramkumar V 2006 Activation of the adenosine A3 receptor in RAW 264.7 cells inhibits lipopolysaccharide-stimulated tumor necrosis factor-alpha release by reducing calcium-dependent activation of nuclear factor-kappaB and extracellular signal-regulated kinase 1/2. J Pharmacol Exp Ther 316:71-78

14. Sajjadi FG, Takabayashi K, Foster AC, Domingo RC, Firestein GS 1996 Inhibition of TNF-alpha expression by adenosine: role of A3 adenosine receptors. J Immunol $156: 3435-3442$

15. Linden J, Taylor HE, Robeva AS, Tucker AL, Stehle JH, Rivkees SA, Fink JS, Reppert SM 1993 Molecular cloning and functional expression of a sheep A3 adenosine receptor with widespread tissue distribution. Mol Pharmacol 44:524-532

16. Stehle JH, Rivkees SA, Lee JJ, Weaver DR, Deeds JD, Reppert SM 1992 Molecular cloning and expression of the cDNA for a novel A2-adenosine receptor subtype. Mol Endocrinol 6:384-393

17. Thiele A, Kronstein R, Wetzel A, Gerth A, Nieber K, Hauschildt S 2004 Regulation of adenosine receptor subtypes during cultivation of human monocytes: role of receptors in preventing lipopolysaccharide-triggered respiratory burst. Infect Immun 72:1349-1357

18. Tucker AL, Linden J 1993 Cloned receptors and cardiovascular responses to adenosine. Cardiovasc Res 27:62-67

19. Stoltz DA, Nelson S, Kolls JK, Zhang P, Bohm RP, Murphey-Corb M, Bagby GJ 2002 Effects of in vitro ethanol on tumor necrosis factor-alpha production by blood obtained from simian immunodeficiency virus-infected rhesus macaques. Alcohol Clin Exp Res 26:527-534

20. Pfaffl MW 2001 A new mathematical model for relative quantification in real-time RT-PCR. Nucleic Acids Res 29:e45

21. Jacobson KA, Park KS, Jiang JL, Kim YC, Olah ME, Stiles GL, Ji XD 1997 Pharmacological characterization of novel A3 adenosine receptor-selective antagonists. Neuropharmacology 36:1157-1165

22. Kim YC, Ji X, Melman N, Linden J, Jacobson KA 2000 Anilide derivatives of an 8 -phenylxanthine carboxylic congener are highly potent and selective antagonists at human $\mathrm{A}(2 \mathrm{~B})$ adenosine receptors. J Med Chem 43:1165-1172

23. Kim YC, Ji XD, Jacobson KA 1996 Derivatives of the triazoloquinazoline adenosine antagonist (CGS15943) are selective for the human A3 receptor subtype. J Med Chem 39:4142-4148

24. Ongini E, Dionisotti S, Gessi S, Irenius E, Fredholm BB 1999 Comparison of CGS 15943, ZM 241385 and SCH 58261 as antagonists at human adenosine receptors. Naunyn Schmiedebergs Arch Pharmacol 359:7-10

25. Murphree LJ, Sullivan GW, Marshall MA, Linden J 2005 Lipopolysaccharide rapidly modifies adenosine receptor transcripts in murine and human macrophages: role of NF-kappaB in A(2A) adenosine receptor induction. Biochem J 391:575-580

26. Takahashi HK, Iwagaki H, Hamano R, Wake H, Kanke T, Liu K, Yoshino T, Tanaka N, Nishibori M 2007 Effects of adenosine on adhesion molecule expression and cytokine production in human PBMC depend on the receptor subtype activated. Br J Pharmacol 150:816-822

27. Takahashi HK, Kanke T, Liu K, Yoshino T, Sendo T, Tanaka N, Nishibori M 2007 Adenosine A2A-receptor stimulation inhibits lipopolysaccharide-induced interleukin-18 production in monocytes. J Pharmacol Sci 104:183-186

28. Jhaveri KA, Toth LA, Sekino Y, Ramkumar V 2006 Nitric oxide serves as an endogenous regulator of neuronal adenosine A1 receptor expression. J Neurochem 99:42-53

29. Le Vraux V, Chen YL, Masson I, De Sousa M, Giroud JP, Florentin I, ChauvelotMoachon L 1993 Inhibition of human monocyte TNF production by adenosine receptor agonists. Life Sci 52:1917-1924

30. Harada N, Okajima K, Murakami K, Usune S, Sato C, Ohshima K, Katsuragi T 2000 Adenosine and selective $\mathrm{A}(2 \mathrm{~A})$ receptor agonists reduce ischemia/reperfusion injury of rat liver mainly by inhibiting leukocyte activation. J Pharmacol Exp Ther 294:1034-1042

31. Zhong H, Wu Y, Belardinelli L, Zeng D 2006 A2B adenosine receptors induce IL-19 from bronchial epithelial cells, resulting in TNF-alpha increase. Am J Respir Cell Mol Biol 35:587-592

32. Levy O, Coughlin M, Cronstein BN, Roy RM, Desai A, Wessels MR 2006 The adenosine system selectively inhibits TLR-mediated TNF-alpha production in the human newborn. J Immunol 177:1956-1966

33. Ezeamuzie CI, Philips E 2003 Positive coupling of atypical adenosine A3 receptors on human eosinophils to adenylyl cyclase. Biochem Biophys Res Commun 300:712-718

34. Palmer TM, Harris CA, Coote J, Stiles GL 1997 Induction of multiple effects on adenylyl cyclase regulation by chronic activation of the human A3 adenosine receptor. Mol Pharmacol 52:632-640

35. Horrigan LA, Kelly JP, Connor TJ 2004 Caffeine suppresses TNF-alpha production via activation of the cyclic AMP/protein kinase A pathway. Int Immunopharmacol 4:1409-1417

36. Majumdar S, Aggarwal BB 2003 Adenosine suppresses activation of nuclear factorkappaB selectively induced by tumor necrosis factor in different cell types. Oncogene 22:1206-1218 